\title{
Application of FTA and SPAR-H Method to Control Work Accident at PG. Krebet Baru
}

\author{
Yedija Prasetya $\mathrm{Wijaya}^{1}$, Sunday Alexander Theophilus Noya ${ }^{2}$
}

\begin{abstract}
This research is conducted because a high number of accidents occured during the workplace in PG. Krebet Baru. There were about 45 accidents in 2013 and 32 out of 45 accidents came from the Maintenance Division. This research is needed for the purpose of decreasing the number of accidents. The methods used in this research are hierarchycal task analysis (HTA), standarized plant risk analysis human reliability assessment (SPAR-H), and fault tree analysis (FTA). In this research, there are 4 stations. They are milling station, purification, maturation, and spinning. Based on this research, there are 5 accidents. They are damaged muscle, damaged bone, graze, damaged eye, and injuries from a fall. Based on this research, it can be concluded that the workplace conditions and the lack of worker awareness on the importance of protective equipment usage are the main causes of these work accidents. Based on these causes, the suitable solution is to change several work methods and instruct the workers about using protective equipment.
\end{abstract}

Keywords. standarized plant risk analysis, work accident, fault tree analysis, hierarchycal task analysis.

\begin{abstract}
Abstrak. Penelitian ini dilakukan karena tingginya angka kecelakaan kerja di PG. Krebet Baru. Ada sekitar 45 kecelakaan pada 2013 dan 32 dari 45 kecelakaan terjadi pada Divisi Pemeliharaan. Penelitian ini diperlukan untuk mengurangi jumlah kecelakaan. Metode yang digunakan dalam penelitian ini adalah analisis tugas terhirarki (HTA), analisis risiko dan keandalan manusia (SPARH), dan analisis pohon kesalahan (FTA). Terdapat 4 stasiun yang diamati, yaitu stasiun giling, pemurnian, masakan, dan putaran. Berdasarkan penelitian ini, ada 5 jenis kecelakaan, yaitu kerusakan otot, kerusakan tulang, luka gores, mata rusak, dan luka-luka dari jatuh. Berdasarkan penelitian ini disimpulkan bahwa kondisi tempat kerja dan kurangnya kesadaran pekerja tentang pentingnya penggunaan alat pelindung adalah penyebab utama dari kecelakaan kerja tersebut. Berdasarkan penyebab ini, solusi yang cocok adalah mengubah beberapa metode kerja dan menginstruksikan para pekerja tentang penggunaan alat pelindung.
\end{abstract}

Kata kunci. analisis tugas terhirarki, analisis risiko dan keandalan manusia, analisis pohon kesalahan, kecelakaan kerja.

\section{INTRODUCTION}

In our industrial world, safety and occupational health are very important aspects. An accident that occur during a production in an industry can cause a disturbance in the work, and

\footnotetext{
${ }^{1}$ Yedija Prasetya Wijaya, Industrial Eng. Study Program, Ma Chung University. Villa PuncakTidar No. 01, Malang (email: 411110019@student.machung.ac.id)

${ }^{2}$ Sunday Alexander Theophilus Noya, Industrial Eng. Study Program, Ma Chung University. Villa PuncakTidar No. 01, Malang (email: sunday.alexander@machung.ac.id)
}

moreover can stop the production. However in Indonesia, safety and occupational health are often neglected and have been considered unimportant. It has been proven by ILO research that concerning safety and occupational health, Indonesia is ranked $152^{\text {th }}$ out of 153 countries.

PG. Krebet Baru (PGKB) is one of the stateowned companies that produce sugar. In PGKB, there are several activities such as milling, purification, maturation, spinning, and maintenance. PGKB has a risk management that is still inadequate. It has been proven from work accident data that in 2013 there were 45 work accidents in PGKB with 32 of 45 work accidents coming from maintenance activity, with the most often-occurring work accident being a damaged muscle. 
Heinrich (1980) on the domino theory of accident causation said that the causes of accidents can be divided in three types. They are unsafe action, unsafe condition, and unavoidable cause. The domino theory of accident causation also states that $88 \%$ of accidents are caused by unsafe action. From the domino theory of accident causation, we can conclude that unsafe action is the most common cause of work accidents.

In order to control the work accidents in the maintenance division PT. PG. Krebet Baru, this research will use SPAR-H method. SPAR-H is one of several methods that can measure the probability of unsafe action, which is the most common work accident cause. This method uses several factors such as available time, stress, complexity, experience and training, ergonomics, procedure, fitness for duty, and work process. Using these factors, the causes of high probability can be known as well. Then, based on the causes, a suitable solution such as more instruction, a proposal for a more suitable work method, and so on, can be determined.

There were several research studies that were already conducted and were used for this research. They are a research study conducted by Harahap (2012) and Sijabat and Noya (2010) about work accident control using SPAR-H method. Those two research studies both use SPAR-H method, but this research study also uses the FTA and HTA method.

\section{Methodology}

The research was conducted from February to May 2015 in PGKB. Here is the sequence of methodology that has been used in this research:

1. Preliminary Observation. The purpose of this stage was to identify the problem occur in PT. PG. Krebet Baru. There were two things to do in this stage observation and a discussion. Taking observations and having a discussion with company's staff made it possible to understand the company's daily maintenance condition and the problems that may occur with daily maintenance.

2. Data Collection. There are two types of data that have been used in this research. They are primary data and secondary data. Primary data can be achieved with an interview or a direct observation. The primary data in this research is data maintenance job. Secondary data can be achieved by asking for data from the company's staff. Secondary data in this research is work accident data and a literature review that is related to the research.

3. Identifying the Sequence of Maintenance Jobs Using Hierarchycal Task Analysis (HTA). The purpose of this stage is to know the steps of work maintenance and to identify the potential work accidents that may occur on each step using hierarchical task analysis (HTA). HTA is a method used to understand the work steps where the result usually becomes the next step starting point. There are several steps in HTA method. They are to identify the work object with the defined restriction and defined scope of the object, break the entire work into work elements with the appropriate sequence of work, determine a stopping rule used to limit the breakdown of work into the elements of work, breakdown the work, and group several overly-detailed work elements into one group.

4. Risk Assessment Using Standardized Plant Risk Analysis Human Reliability Assessment (SPAR-H). The purpose of this stage is to calculate the probability of the occurrence of the work accident on each step of maintenance work using SPAR-H method. SPAR-H method is a method that is used to calculate human error probability (HEP) based on the performance shaping factor (PSF). PSF value indicates the level of human error when doing an activity. There are several PSF factors that can be seen in Table 1.

\section{Determining the PSF value}

Available time is the availability of the time use to complete the task. There are five categories of assessment in available time, that is inadequate time, time available equal to time required, nominal time, time available $>5 \mathrm{x}$ time required, time available $>50 \mathrm{x}$ time required, and insufficient information. Inadequate time is chosen if the available time is not enough for worker to complete the task. Time available equal to time required is chosen if amount of available time is equal to time required for complete the 
Table 1. Performance Shaping Factor (PSF)

\begin{tabular}{|c|c|c|}
\hline SPAR-H PSF's & SPAR-H PSF Levels & SPAR-H Multipliers \\
\hline \multirow{5}{*}{ Available Time } & Inadequate Time & P Failure $=1,0$ \\
\hline & Time Available $=$ Time Required & 10 \\
\hline & Nominal Time & 1 \\
\hline & Time Available $\geq 5 x$ Time Required & 0.1 \\
\hline & Time Available $\geq 50 x$ Time Required & 0.001 \\
\hline \multirow{3}{*}{ Stress/Stressors } & Extreme & 5 \\
\hline & High & 2 \\
\hline & Nominal & 1 \\
\hline \multirow{3}{*}{ Complexity } & Highly Complex & 5 \\
\hline & Moderately Complex & 2 \\
\hline & Nominal & 1 \\
\hline \multirow{3}{*}{ Experience/Turning } & Low & 3 \\
\hline & Nominal & 1 \\
\hline & High & 0.5 \\
\hline \multirow{4}{*}{ Procedures } & Not Available & 50 \\
\hline & Incomplete & 20 \\
\hline & Available, but poor & 5 \\
\hline & Nominal & 1 \\
\hline \multirow{4}{*}{ Ergonomic/HMI } & Missing/Misleading & 50 \\
\hline & Poor & 10 \\
\hline & Nominal & 1 \\
\hline & Good & 0.5 \\
\hline \multirow{3}{*}{ Fitness for Duty } & Unfit & $\mathrm{P}$ Failure $=1,0$ \\
\hline & Degraded Fitness & 5 \\
\hline & Nominal & 1 \\
\hline \multirow{3}{*}{ Work Process } & Poor & 2 \\
\hline & Nominal & 1 \\
\hline & Good & 0.8 \\
\hline
\end{tabular}

task. Nominal time is chosen if the available time is longer than the time required for complete the task. Time available $>5 \mathrm{x}$ time required is chosen if the ratio of the available time and time required is 5:1. Time available $>50 \mathrm{x}$ time required is chosen if the ratio of the available time and time required is 50:1. Insufficient information is chosen if the information is not enough to determine the categories of assessment.

Stress is a measurement of the level of manpower while doing work. There are five categories of assessment in stress: extreme, high, nominal, and insufficient information. Extreme is chosen if the work pressure experienced by the workers is great and makes the performance of the workers fall dramatically. High is chosen if the work pressure experienced by the worker is great but it does not affect the work performance. Nominal is chosen if the work pressure experienced by the worker is normal and don't affect anything. Insufficient information is chosen if the information is not enough to determine the categories of assessment.

Complexity is the level of difficulty the job and the amount of effort a worker needs to get the job done. There are five categories of assessment in complexity: highly complex, moderately complex, nominal, obvious diagnosis, and insufficient information. Highly complex is chosen if this job is very difficult and requires much effort to get the job done. Moderately complex is chosen if the job is difficult and requires several steps to get the job done. Nominal is chosen if the job is simple. Obvious diagnosis is chosen if the job is very simple and easy. Insufficient information is chosen if the information is not enough to determine the categories of assessment

Experience and training is the level of experience and training that the workers possess 
to get the job done. There are four categories of assessment in experience and training: low, nominal, high, and insufficient information. Low is chosen if the worker experience and training is less than six month, which is not enough to get the job done. Nominal is chosen if the worker experience and training is enough to get the job done. High is chosen if the worker has a lot experience and training that is useful for doing the job. Insufficient information is chosen if the information is not enough to determine the categories of assessment.

Procedures measure the amount of instructional cues used by the company. There are six categories of assessment in procedure: not available, incomplete, available but poor, nominal, diagnostic oriented, and insufficient information. Not available is chosen if there are no procedures for the job. Incomplete is chosen if there is a procedure but not for the whole job. Available but poor is chosen if there is a complete procedure for the job but its difficult to understand and difficult to execute the procedure in the job. Nominal is chosen if there are a appropriate cues or procedures for the job. Diagnostic oriented is chosen if there is a procedure for diagnosis. Insufficient information is chosen if the information is not enough to determine the categories of assessment.

Ergonomics is the measure of the quality of information, equipment, layout and displays that come with the job. There are four categories of assessment in ergonomics: poor, nominal, good, and insufficient information. Poor is chosen if layout and other ergonomic factors are not good and give a negative effect to worker performance. Nominal is chosen if the layout and other factors are good but do not help the worker do the job. Good is chosen if the layout and other factors are very good and minimize the probability of a work accident. Insufficient information is chosen if the information is not enough to determine the categories of assessment.

Fitness for duty is about a worker's physical and mental condition when doing the job. There are four categories of assessment in fitness for duty that is unfit, degraded fitness, nominal, and insufficient information. Unfit is chosen if the worker is sick before doing the job. Degraded fitness is chosen if the worker is unwell while doing the job. Nominal is chosen if the worker is okay while doing the job. Insufficient information is chosen if the information is not enough to determine the categories of assessment.

Work process is about management policy such as safety culture, work planning, and communication between employees. There are four categories in assessing work process: poor, nominal, good, and insufficient information. Poor is chosen if the work process negatively affects the worker performance such as a no safety culture and bad communication. Nominal is chosen if the work process is appropriate but does not give a good effect to worker performance. Good is chosen if the work process is good, appropriate, and can increase worker performance. Insufficient information is chosen if the information is not enough to determine the categories of assessment.

Once the assessment is decided on for each factor, then the next step calculates the human error probabilities (HEP). The HEP calculation divides activities into two types, which are diagnosis activities and action activities. On diagnosis activities the value of failure probabilities is 0.01 and on action activities the value of failure probabilities is 0.001 . The formula to calculate the HEP is as follow (Harahap, 2012):

\section{HEP $=$ Failure Probabilities $*$ Time $*$ Stress $*$ Complexity ${ }^{*}$ Experience $*$ Procedur* Ergonomics*Fitness For Duty* Work Process}

And if there are three factors that have a negative value, the formula to calculate the HEP is as follow:

$$
H E P=\frac{N H E P * P S F \text { Composite }}{N H E P *(P S F \text { Composite }-1)+1}
$$

SPAR-H method also incorporates the impact that failure of one task will have on an entire range of the work tasks; this is called dependency. On SPAR-H, dependency is affected by four factors, which are crew, time, location, and cues. Crew states whether a series of work tasks are performed by the same person $(s)$ or not $(D)$. Time states whether the work is done in a 
Table 2. SPAR-H dependency

\begin{tabular}{cccccc}
\hline No & Crew & Time & Location & Cues & Dependency \\
\hline 1 & $\mathrm{~S}$ & $\mathrm{C}$ & $\mathrm{S}$ & $\mathrm{Na}$ & Complete \\
2 & $\mathrm{~S}$ & $\mathrm{C}$ & $\mathrm{S}$ & $\mathrm{A}$ & Complete \\
3 & $\mathrm{~S}$ & $\mathrm{C}$ & $\mathrm{D}$ & $\mathrm{Na}$ & High \\
4 & $\mathrm{~S}$ & $\mathrm{C}$ & $\mathrm{D}$ & $\mathrm{A}$ & High \\
5 & $\mathrm{~S}$ & $\mathrm{Nc}$ & $\mathrm{S}$ & $\mathrm{Na}$ & High \\
6 & $\mathrm{~S}$ & $\mathrm{Nc}$ & $\mathrm{S}$ & $\mathrm{A}$ & Moderate \\
7 & $\mathrm{~S}$ & $\mathrm{Nc}$ & $\mathrm{D}$ & $\mathrm{Na}$ & Moderate \\
8 & $\mathrm{~S}$ & $\mathrm{Nc}$ & $\mathrm{D}$ & $\mathrm{A}$ & Low \\
9 & $\mathrm{D}$ & $\mathrm{C}$ & $\mathrm{S}$ & $\mathrm{Na}$ & Moderate \\
10 & $\mathrm{D}$ & $\mathrm{C}$ & $\mathrm{S}$ & $\mathrm{A}$ & Moderate \\
11 & $\mathrm{D}$ & $\mathrm{C}$ & $\mathrm{D}$ & $\mathrm{Na}$ & Moderate \\
12 & $\mathrm{D}$ & $\mathrm{C}$ & $\mathrm{D}$ & $\mathrm{A}$ & Moderate \\
13 & $\mathrm{D}$ & $\mathrm{Nc}$ & $\mathrm{S}$ & $\mathrm{Na}$ & Low \\
14 & $\mathrm{D}$ & $\mathrm{Nc}$ & $\mathrm{S}$ & $\mathrm{A}$ & Low \\
15 & $\mathrm{D}$ & $\mathrm{Nc}$ & $\mathrm{D}$ & $\mathrm{Na}$ & Low \\
16 & $\mathrm{D}$ & $\mathrm{Nc}$ & $\mathrm{D}$ & $\mathrm{A}$ & Low \\
17 & & & & & Zero \\
\hline
\end{tabular}

series of adjacent times $(C)$ or not $(N c)$. Location states whether the work occurs in the same location $(S)$ or different $(D)$.Cues state whether a series of such work tasks have the appropriate procedures $(A)$ or not $(N a)$. Table 2 shows the dependency SPAR-H method (Harahap, 2012).

Once the level of dependency is decided, the next step will be calculate the HEP based on dependency (Harahap, 2012):

1. On complete dependency the value of HEP is 1.

2. On high dependency the value of HEP is

$$
\left(H E P+\frac{\left(1 * H E P_{\text {before }}-1\right)}{2}\right)
$$

3. On moderate dependency the value HEP is

$$
\left(H E P+\frac{\left(6 * H E P_{\text {before }}\right)}{13}\right)
$$

4. On low dependency the value of HEP is

$$
\left(H E P+\frac{\left(9 * H E P_{\text {before }}\right)}{20}\right)
$$

5. On zero dependency the value of HEP is the same with $H E P_{\text {before }}$.

\section{Calculate total HEP}

The purpose of this stage is to calculate total HEP in one workstation using FTA and find the main causes of high HEP by analyzing the SPAR$\mathrm{H}$ factor. Quantitative analysis in FTA is divided into 2 types, which are the AND gate and the OR gate. On calculating Total HEP, And Gate Logic will be used if the top event will occur when the all the input events occurrence. Figure 1 shows a single AND-gate picture (Harahap, 2012).

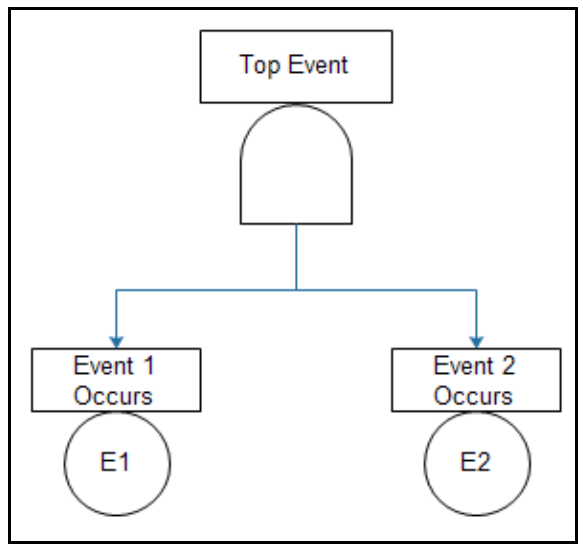

Figure 1. Single AND-Gate

The formula to calculate the AND gate logic is as follow:

$$
\begin{aligned}
Q_{0}(t) & =P_{r}(E 1(t) \cap E 2(t)) \\
& =P_{r}(E 1(t)) \cdot P_{r}(E 2(t))
\end{aligned}
$$

Or the formula to calculate AND-Gate logic in m event is as follows:

$Q_{0}(t)=\prod_{j=1}^{m} q j(t)$

OR gate logic will be used if the top event will occur when one of the input events occur. Figure 2 shows a single OR gate picture (Harahap, 2012). 


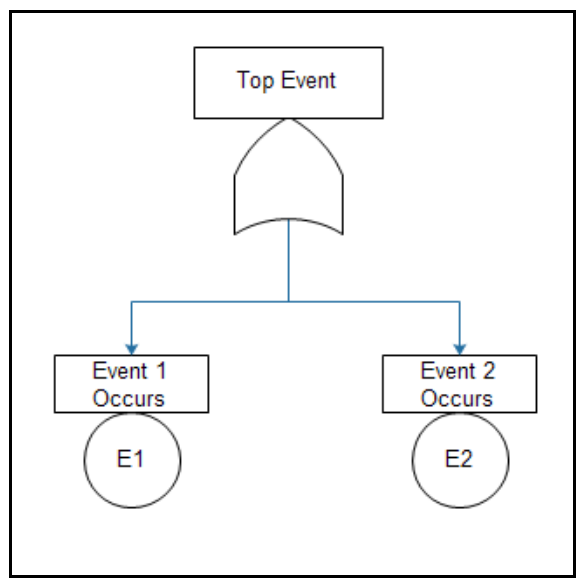

Figure 2. Single OR-Gate

The formula to calculate the OR gate logic is as follow:

$$
\begin{aligned}
& Q_{0}(t)=P_{r}(E 1(t) \cap E 2(t)) \\
& \quad=P_{r}(E 1(t))+P_{r}(E 2(t))-P_{r}(E 1(t)) \cdot P_{r}(E 2(t))
\end{aligned}
$$

Or the formula to calculate OR-Gate logic in $m$ event is as follows:

$$
Q_{0}(t)=1-\prod_{j=1}^{m}(q j(t))
$$

Using AND gate and OR gate logic, the probability of each work accident in each station can be calculated. From that probability the most common work accident can be calculated as well. In this stage, an analysis for looking at the main causes of these problems will be conducted too. This analysis will be conducted based on the SPAR-H factor to find out the main cause of work accidents whether it be available time, complexity, or experience and training.

\section{Making a suitable recommendation based on the causes and conclusion}

Once the main cause of the work accident is known, the next step will be to make a suitable recommendation based on the causes. The suitable solution can be a new SOP, or some instruction to the worker based on the analysis.

In conclusion, a recommendation analysis will be conducted and conclusions will be made. In recommendation analysis, an interview with the supervisor will be conducted. The purpose of this interview is to predict the probability of work accidents if the recommendations have been implemented. The next step will be making conclusions, which will be made based on the research results.

\section{RESULT AND ANALYSIS}

\section{Work accident identification}

This research just focused on maintenance activities. There are thirteen maintenance work tasks within 4 areas of maintenance activities. There are three kinds of maintenance work in milling station which are to repair the pump, repair the scrapper, and repair the intermediate carrier. There are five kinds of maintenance work in purification station, which are repair the pump, repair the sedimentation vessel, repair the sulfitation vessel, repair the juice heater and repair the raw juice vessel. There are three types of maintenance work in the maturation station, to

\begin{tabular}{|c|c|c|c|}
\hline Step & Task & Accident's scenario & Risk \\
\hline 0 & Repair the pump & & \\
\hline \multirow[t]{2}{*}{1} & Disassemble the pump & $\begin{array}{l}\text { Body position is not right when lifting the component } \\
\text { and cause damaged muscle }\end{array}$ & Damaged muscle \\
\hline & & $\begin{array}{l}\text { The hand position is not right and the machine } \\
\text { component accidentally slipped when the worker lifted } \\
\text { the component }\end{array}$ & Damaged bone \\
\hline \multirow[t]{2}{*}{2} & Replace the bearing & Body position is not right when replacing the bearing & Damaged muscle \\
\hline & & $\begin{array}{l}\text { The worker was grazed by the pulley when replacing } \\
\text { the bearing }\end{array}$ & Grazed \\
\hline 3 & Replace the seal & - & - \\
\hline 4 & $\begin{array}{l}\text { Weld the broken } \\
\text { pump's case }\end{array}$ & $\begin{array}{l}\text { The worker not wear the eye protector when welding } \\
\text { and the spark touch the eye }\end{array}$ & Damaged eye \\
\hline 5 & Assemble the pump & Body position is not right when assembling the pump & Damaged muscle \\
\hline
\end{tabular}
repair the A, C, and D vessel. There are two types

Table 3. Repair the pump work accident identification 
Table 4. Repair the pump HEP caluculation

\begin{tabular}{lccccc}
\hline \multirow{2}{*}{ Factor Multiplier } & \multicolumn{5}{c}{ Task Step } \\
\cline { 2 - 6 } & 1 & 2 & 3 & 4 & 5 \\
\hline Available Time & 1 & 1 & - & 1 & 1 \\
Stress & 2 & 2 & - & 2 & 2 \\
Complexity & 1 & 1 & - & 1 & 1 \\
Experience & 3 & 3 & - & 3 & 3 \\
Procedure & 1 & 1 & - & 5 & 1 \\
Ergonomics & 1 & 1 & - & 1 & 1 \\
Fitness for duty & 1 & 1 & - & 1 & 1 \\
Work Process & 1 & 1 & - & 1 & 1 \\
PSF Composite & 6 & 6 & - & 30 & 6 \\
NHEP & 0.001 & 0.001 & - & 0.001 & 0.001 \\
HEP & 0.006 & 0.006 & - & 0.03 & 0.006 \\
\hline
\end{tabular}

Table 5. Repair the pump HEP with dependency calculation

\begin{tabular}{|c|c|c|c|c|c|c|c|c|c|}
\hline No & $\begin{array}{l}\text { Maintenance } \\
\text { work }\end{array}$ & Task Description & HEP & Crew & Time & Location & Cues & $\begin{array}{l}\text { Depend- } \\
\text { ency }\end{array}$ & HEP \\
\hline \multirow[t]{5}{*}{1} & \multirow{5}{*}{$\begin{array}{l}\text { Repair The } \\
\text { pump }\end{array}$} & Disassemble the pump & 0.006 & $S$ & $\mathrm{Nc}$ & $\mathrm{D}$ & A & Low & 0.008 \\
\hline & & Replace the bearing & 0.006 & $\mathrm{~S}$ & $\mathrm{Nc}$ & $\mathrm{D}$ & $\mathrm{A}$ & Low & 0.008 \\
\hline & & Replace the seal & - & - & - & - & - & - & - \\
\hline & & $\begin{array}{l}\text { Weld the broken pump } \\
\text { case }\end{array}$ & 0.03 & $\mathrm{~S}$ & $\mathrm{Nc}$ & $\mathrm{D}$ & A & Low & 0.043 \\
\hline & & Assemble the pump & 0.006 & $\mathrm{~S}$ & $\mathrm{Nc}$ & $\mathrm{D}$ & $\mathrm{A}$ & Low & 0.008 \\
\hline
\end{tabular}

of maintenance work in the spinning station, which are to repair the pump, and repair the sugar elevator. Out of 13 maintenance jobs, there are 5 types of work accident that have been identified. They are damaged muscle, damaged bone, damage by being grazed, injuries from a fall, and damaged eye. Table 3 is one out of thirteen result of HTA and work accident identification.

\section{HEP calculation}

Once each work accident is already known, the next step will be to calculate the human error probabilities using the SPAR-H method. The example of the HEP calculation using the SPAR$\mathrm{H}$ method can be seen in Table 4. The next step after the HEP calculation is the HEP with dependency calculation using SPAR-H. The example of the HEP with dependency calculation can be seen in the Table 5. After calculating that, the result will be each job's HEP with dependency probability. Once it's done, the next step will be calculating total HEP using AND gate or OR gate logic. The example of the total HEP calculation can be seen in Figure 3 and the total HEP from all of the maintenance work can be seen in Table 6 .

Based on Table 6, the most common work accident is a damaged muscle in the purification station with a probability of 0.304 . The second common work accident is injuries from a fall and damaged bone in the maturation station with the probability of 0.114 . The third common work accident is damaged eye in milling station with a probability of 0.079 . From this we can conclude that they are the most frequently occur work accidents because of the human error.

\section{Causes analysis and recommendation for damaged muscle}

There are three activities on milling station and two activities on the spinning station that can cause damaged muscle: repairing the pump, repairing the scrapper, repairing intermediate carrier, and repair the sugar elevator. The main cause of damaged muscle in these three activities is the lack of appropriate instruction which is used to repair the machine. Based on that, the suitable recommendation will be giving appropriate instruction to the maintenance workers about how to repair the machine without 


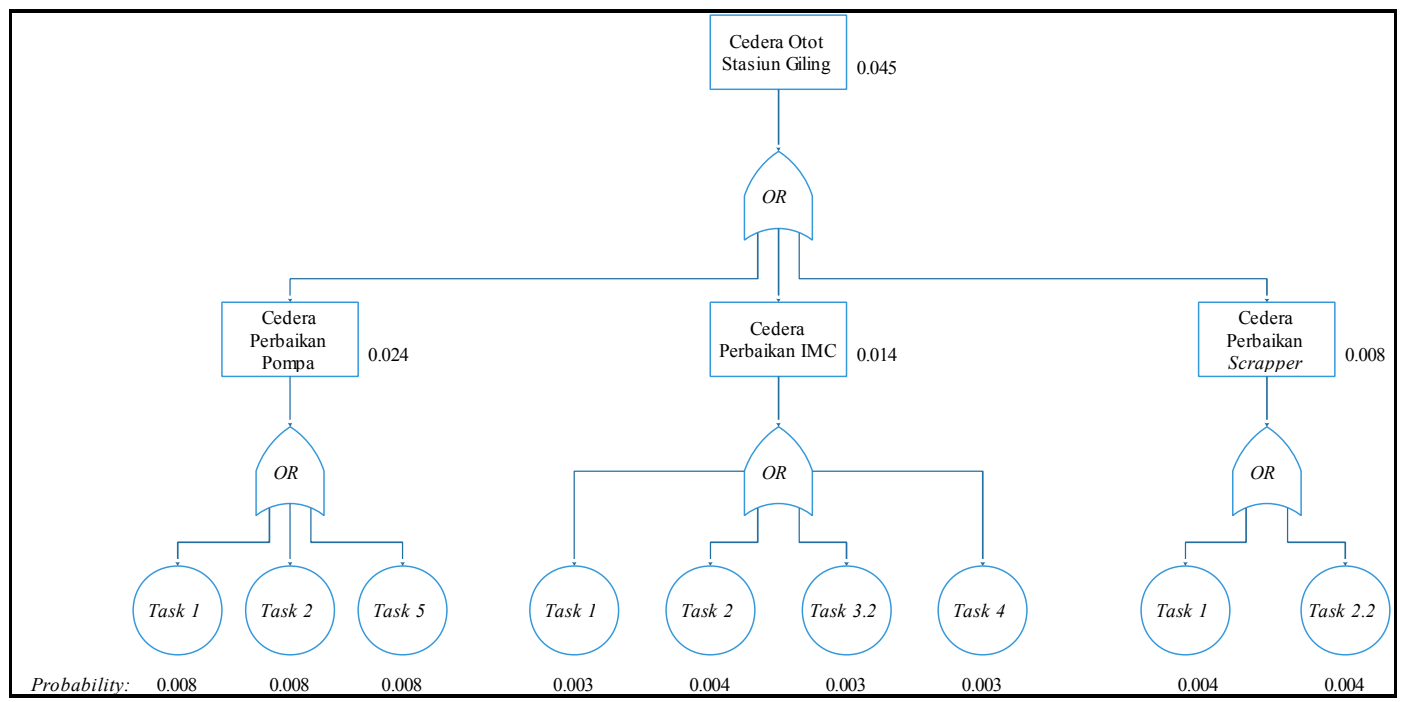

Figure 3. Total HEP calculation for damaged muscle in milling station

Table 6. Total HEP in the Maintenance Division

\begin{tabular}{clc}
\hline No & \multicolumn{1}{c}{ Work Accident } & Total HEP \\
\hline 1 & Damaged muscle in milling station & 0.045 \\
2 & Damaged eye in milling station & 0.079 \\
3 & Damaged bone in milling station & 0.015 \\
4 & Grazed in milling station & 0.016 \\
5 & Damaged muscle in purification & 0.304 \\
6 & Damaged eye in purification & 0.043 \\
7 & Injuries from fall in purification & 0.05 \\
8 & Damaged bone in purification & 0.046 \\
9 & Grazed in purification & 0.008 \\
10 & Injuries from fall in maturation & 0.114 \\
11 & Damaged bone in maturation & 0.114 \\
12 & Damaged muscle in spinning & 0.048 \\
13 & Damaged eye in spinning & 0.048 \\
14 & Damaged bone in spinning & 0.008 \\
15 & Grazed in spinning & 0.013 \\
\hline
\end{tabular}

suffering a damaged muscle. The appropriate instruction that will be given to the worker is when lifting weights (manual lifting) the worker must carry the load as close to the body as possible and does not lift past his waist height. When carrying the component, the closer to the axis of the body the better, because the pressure on the spine will be less than when it far from the axis of body. The operator is also directed not to rotate his body when carrying components of a heavy machine. In addition the operator must avoid excessive exertion on all muscles at the same time and if possible rotate the job every month.
On the purification station, there are four activities that cause damaged muscle: repairing the pump, repairing the sedimentation vessel and sulphitation vessel, repairing the raw juice vessel, and repairing the juice heater. The main causes to damaged muscle are an ergonomic factor and the manual repair method that has been used to repair the vessel. Based on that damage, the suitable solution will be to implement a new repair method using super descaler. Super descaler is a chemical liquid that prevents crust and corrosion. By using super descaler, the worker can repair the vessel without suffering a damaged muscle because the worker can repair the vessel without 
entering and scrubbing the wall inside the vessel.

\section{Recommendation for damaged eye}

On PGKB, a damaged eye can happen in three stations: the milling station, purification station, and spinning station. The main cause of damaged eye is unaware of how important it is to use an APD, especially an eye protector. The eye protector can prevent the eye suffering damage from the sparks.

The eye protector for welding must be darkly colored to keep out the UV rays. Another safety measure that worker must use is goggles. Even though the worker is already using the eye protector, the worker must wear goggles to protect the eye from loose fragments when the worker opens the eye protector.

\section{Recommendation for injuries from fall}

Injuries from a fall happen in purification station and maturation station. The main cause of injuries from a fall is falling from a ladder and a slippery work location. Based these causes, the suitable solution is to give instructions to wear boots made of rubber, to wear a safety belt when using ladder, and to repair the ladder. Using rubber boots can prevent the worker from slipping on the ladder. Using a safety belt will prevent injuries from a fall when the worker repairs the tank.

\section{Recommendation from damaged bone}

Damaged bone can happen in all of the stations. The main cause of a damaged bone is a worker's recklessness, and the condition of the work location. Based on these causes the suitable solution will be to give instructions to wear boots made of rubber, to wear a safety belt when using ladder, and give instructions about the right method for lifting the machine's components. Using rubber boots can prevent the worker slipping on the ladder. Using a safety belt will prevent injuries from a fall when the worker repairs the tank.

\section{Recommendation for grazed hand or body}

Being grazed on the hand or body can be happen in the milling station, purification station, and spinning station. The main cause of a grazed hand or body is worker carelessness when repairing the machine so that the sharp part of the machine grazes the worker's body or hand. Based on that cause, the suitable solution is wearing anti-graze gloves. By wearing the gloves the worker can prevent his hand being grazed while repairing the machine.

\section{Prediction}

Once we know the recommendation for each accident, we can predict the result if we implement the recommendations by discussing it with an expert. For this research, Mr. Sugeng and

Table 7. Prediction result

\begin{tabular}{clccc}
\hline No & \multicolumn{1}{c}{ Work Accident } & Total HEP & Prediction & Improvement \\
\hline 1 & Damaged muscle in milling station & 0.045 & 0.0153 & $66 \%$ \\
2 & Damaged eye in milling station & 0.079 & 0.0057 & $93 \%$ \\
3 & Damaged bone in milling station & 0.015 & 0.0052 & $65 \%$ \\
4 & Grazed in milling station & 0.016 & 0.0057 & $64 \%$ \\
5 & Damaged muscle in purification & 0.304 & 0.0171 & $94 \%$ \\
6 & Damaged eye in purification & 0.043 & 0.0029 & $93 \%$ \\
7 & Injuries from fall in purification & 0.05 & 0.024 & $52 \%$ \\
8 & Damaged bone in purification & 0.046 & 0.022 & $52 \%$ \\
9 & Grazed in purification & 0.008 & 0.0029 & $64 \%$ \\
10 & Injuries from fall in maturation & 0.114 & 0.051 & $55 \%$ \\
11 & Damaged bone in maturation & 0.114 & 0.051 & $55 \%$ \\
12 & Damaged muscle in spinning & 0.048 & 0.01 & $79 \%$ \\
13 & Damaged eye in spinning & 0.048 & 0.0036 & $93 \%$ \\
14 & Damaged bone in spinning & 0.008 & 0.0029 & $64 \%$ \\
15 & Grazed in spinning & 0.013 & 0.0034 & $74 \%$ \\
\hline
\end{tabular}


Mr. Sujarwo will be the experts. Both of them are supervisors in PGKB. The results of this prediction can be seen in Table 7 .

\section{CONCLUSION}

Based on the research that has already been done, there are four stations that are relevant for this research, which are the milling station, purification station, maturation station, and spinning station. For these 4 stations, there are 5 types of work accident that have been identified, which are damaged muscle, damaged eye, damaged bone, injuries from a fall and being grazed. This research also calculates the human error probability for each task in the station, and the result is that a damaged muscle in the purification station is the most common work accident with a probability of 0.304 . Once the calculation is done, this research analyzes the main cause of each work accident and the result is the that the cause of work accidents is using a manual method for repairing a vessel, having the wrong body position when lifting certain components, the equipment's condition, and the worker not realizing the importance of using an APD. Based on that the suitable solution will be a new method on repairing the vessel, instructions on how to lift those component correctly, and instructing worker to use an APD when working.

\section{DAFTAR PUSTAKA}

Harahap, F.A. (2012). Reability Assessment Sebagai Upaya Pengurangan Human Error Dalam penerapan Kesehatan dan Keselamatan Kerja. Skripsi Fakultas Teknik. Universitas Indonesia, Depok.

Heinrich, H.W.; Peterson, D.; Roos, N. (1980). Industrial Accident Prevention. 5th Edition. New York: McGraw Hill.

Sijabat, C.B.; Noya, S.(2014) 'Application of HIRA and SPAR-H method to control work accident'. Jurnal Teknik Industri, Vol. 15 (1), hal. 70 - 79. 